8. Kaji, T., et al. Intestinal Adaptation After A Resection Is Aided by GLP-2 in Rats As Well.- J. PED. Surgery. 44 (8): 1552-1559, 2009

9. Katherine J. Rowland1 and Patricia L. Brubaker1.2. The "Cryptic" Mechanism of Action of Glucagon-Like Peptide2.- Am J Physiol Gastrointest Liver Physiol 301: G1-G8, 2011.

10. Garrison, A.P. Early But Not Lite Administration of Glucagon-Like Peptide-2 Following IleoCecal Resection Augments Putative Intestinal Stem Cell Expansion, et al. Am. J. Physiol. Gastrointest. Liver Physiol. 296: G643G650, 2009)

11. Novosbekov M.S. *, Olisov OD, Glyaev V.A., Lutsyk K.N., Magomedov K.M. Transplantation and autotransplantation as a radical method of treatment with non-cross-tumor tumor and parasitic liver diseases. Annals of surgical hepatology, 2020, volume 25, №4. - C. 49-58.

12. Averyanova Yu.V., Features of the treatment of children with extrahepatic portal hypertension and unsatisfactory results of previously conducted surgical corrections. - EVANT OF DISS. Cand., 2021.-23

\title{
Mehraliyev O.SH.O. \\ Optimization of diagnosis of breast cancer and metastatic lymphonic diseases
}

\author{
Azerbaijan Medical University \\ (Azerbaijan, Baku)
}

doi: 10.18411/gqws-01-2022-08

\section{Abstract}

The survey data of 115 patients with breast cancer and metastatic lymph node lesions were used. The main group included $14(20.0 \%)$ patients of relatively young age (30-40 years), 29 $(41.4 \%)$ of average age (40-50 years), $26(37.1 \%)$ of elderly age (50-60 years) and $1(1.4 \%)$ patient older than 60 years. The main group included, respectively, $5(11.1 \%)$ young patients, $18(40.0 \%)-$ middle-aged, $23(46.7 \%)$ - elderly, 1 (2.2\%) patient older than 60 years. The control group included 30 premenopausal patients, the remaining 40 were postmenopausal. In the main group of premenopausal patients there were 12 and 33 postmenopausal patients.

The results of the survey of patients with the QLQ-B23 questionnaire adopted by the EORTC (European Organization for Research and Treatment of Cancer) were obtained. There was no significant difference between the groups in the domains of the questionnaire "Assessment of future prospects" $(\mathrm{p}=0.003)$. At the same time, in the main group, compared with the control group, there were significantly significant and high results according to the "Side effects of systemic therapy" scale $(22.9 \pm 1.20$ points and $16.1 \pm 0.82$ points, $\mathrm{p}=0.001)$. Patients with diagnosed breast cancer without metastatic lymph node lesions had significantly fewer complaints according to the profile "Side effects from the hand" ( $14.3 \pm 0.82$ points, versus $30.6 \pm 1.91$, in patients with metastatic lymph nodes, $\mathrm{p}=0.001$ ).

The positive dynamics in the picture of the patients' state of health and higher scores of the questionnaires in the control group were revealed. Patients in the main group noted an increase in indicators such as a deterioration in emotional status and a higher level of anxiety.

Patients with metastatic lesions of the lymph nodes on the background of breast cancer have lower self-esteem compared to the control group of patients without lymphastasis due to rejection of the body image, decreased sexual activity.

Keywords: quality of life, breast cancer, lymphastasis, EORTC questionnaire QLQ-BR23.

\section{Аннотация}

Были использованы данные анкетирования 115 пациенток, больных раком молочной железы и метастатическими поражениями лимфоузлов. В основную группу было включено 14 (20,0\%) пациенток сравнительно молодого возраста (30-40 лет), 29 (41,4\%) среднего (4050 лет), 26 (37,1\%) пожилого возраста (50-60 лет) и 1 (1,4\%) пациентка старше 60 лет. В основную группу было включено соответственно $5(11,1 \%)$ пациенток молодого возраста, 18 $(40,0 \%)$ - среднего, $23(46,7 \%)$ - пожилого возраста, 1 (2,2\%) пациентка старше 60 лет. В контрольную группу было включено 30 больных в пременопаузе, остальные 40 находились в 
постменопаузе. В основной группе пациенток в пременопаузе было 12 и 33 больных пациенток в постменопаузе.

Были получены результаты анкетирования пациенток опросником QLQ-B23, принятым EORTC (European Organisation for Research and Treatment of Cancer). Существенной разницы между группами не было зафиксировано по доменам опросника «Оценка будущих перспектив» не отмечено ( $\mathrm{p}=0,003)$. При том, в основной группе, по сравнению с контрольной группой, отмечались достоверно значимые и высокие результаты по данным шкалы «Побочные эффекты системной терапии» $(22,9 \pm 1,20$ балла и $16,1 \pm 0,82$ балла, $\mathrm{p}=0,001)$. У пациенток с диагностированным раком молочной железы без метастатических поражений лимфоузлов было отмечено достоверно меньшее число жалоб по профилю «Побочные эффекты со стороны руки» $(14,3 \pm 0,82$ балла, против 30,6士1,91, у пациенток с метастатическими лимфоузлами, $\mathrm{p}=0,001)$.

Выявлены положительная динамика в картине самочувствия больных и более высокие баллы опросников в контрольной группе. Пациенты же основной группы отмечали увеличение таких показателей, как ухудшение эмоционального статуса и более высокий уровень тревожности. Пациенты с метастатическим поражением лимфатических узлов на фоне рака молочной железы имеют более низкую самооценку в сравнении с контрольной группой пациентов без лимфастазов за счет непринятия образа тела, снижения сексуальной активности.

Ключевые слова: качество жизни, рак молочной железы, лимфастазы, опросник EORTC QLQ-BR23.

Malignant neoplasms, due to their prevalence and in terms of the formation of disability and mortality, are one of the priority medical and social problems in all countries of the world [2,3,4]. Studies of disability among women after surgery for breast cancer in the overwhelming case actualize the medical aspects of this problem, taking into account the regional and sociological aspects [1].

Objective of the study: Improving the efficiency of diagnosis of breast cancer and lymphastasis using quality of life questionnaires.

Materials and methods. We used the data of a questionnaire survey of 115 patients with breast cancer and metastatic lesions of the lymph nodes who were treated at the Republican Cancer Hospital, divided into two groups - the main group, 45 patients with breast cancer with lymphastasis and the control group, 70 patients without lymph node lesions.

EORTC QLQ-B23 consists of 23 questions and 4 functional scales: body image, sexual activity, sexual satisfaction, assessment of future prospects; 4 symptom scores: side effects of systemic therapy, side effects from the breast, arms, hair loss.

The main group included 14 (20.0\%) patients of a relatively young age (30-40 years old), 29 (41.4\%) middle-aged (40-50 years old), 26 (37.1\%) elderly patients (50- 60 years old) and 1 (1.4\%) patient over 60 years old. The main group included, respectively, $5(11.1 \%)$ young patients, 18 $(40.0 \%)$ - middle age, $23(46.7 \%)$ - elderly patients, $1(2.2 \%)$ patient over 60 years old. The control group included 30 premenopausal patients, the remaining 40 were postmenopausal. In the main group of premenopausal patients, there were 12 and 33 postmenopausal patients.

Statistical processing methods Statistical processing of the research results was carried out on a personal computer; for the analysis of the clinical data obtained during the study, the STATISTICA system for Windows 7.0, which is an integrated data processing environment, was used. Comparison of the studied quantitative parameters (age, tumor localization, indicators of the quality of life of patients according to the questionnaire questionnaires QLQ-BR23) in the study groups was carried out using the Mann-Whitney criteria.

Descriptive statistics of quantitative features included the assessment of the arithmetic mean, standard deviation, mean error, minimum and maximum. The criterion for the statistical reliability of the conclusions was the $\mathrm{p}<0.05$ generally accepted in medicine. 
Research results. The results of the questionnaire survey of patients with the QLQ-B23 questionnaire adopted by the EORTC (European Organization for Research and Treatment of Cancer) in patients with breast cancer in two different control and main groups are presented in the following table 1.

There was no significant difference between the groups for the domains of the "Assessment of Future Prospects" questionnaire $(\mathrm{p}=0.003)$. Moreover, in the main group, compared with the control group, there were significantly significant and high results according to the scale "Side effects of systemic therapy" ( $22.9 \pm 1.20$ points and $16.1 \pm 0.82$ points, $p=0.001)$. Patients with diagnosed breast cancer without metastatic lesions of the lymph nodes had a significantly lower number of complaints according to the profile "Side effects from the hand" (14.3 \pm 0.82 points, versus $30.6 \pm 1.91$, in patients with metastatic lymph nodes , $\mathrm{p}=0.001$ ).

Table 1

Indicators of the QLQ-BR-23 questionnaire in patients of the control and main groups

\begin{tabular}{|c|c|c|c|}
\hline \multirow{2}{*}{ EORTC QLQ-B23 } & $\begin{array}{c}\text { Control } \\
\text { group } \\
(n=70)\end{array}$ & Main group (n=45) & $P$ \\
\cline { 2 - 4 } & $($ балль) & (балль) & \\
\hline Body image & $85,0 \pm 0,75$ & $58,9 \pm 1,14$ & $0,001 *$ \\
\hline Sexual activity & $18,1 \pm 2,00$ & $6,7 \pm 2,01$ & $0,001 *$ \\
\hline Assessment of future prospects & $58,6 \pm 2,58$ & $46,7 \pm 2,68$ & $0,003 *$ \\
\hline Side effects of systemic therapy & $16,1 \pm 0,82$ & $22,9 \pm 1,20$ & $0,001 *$ \\
\hline Hand side effects & $14,3 \pm 0,82$ & $30,6 \pm 1,91$ & $0,001 *$ \\
\hline
\end{tabular}

Note: * - the difference in the indicator is statistically significant relative to main group $(p<0.05)$ (according to Mann-Whitney U-test)

It should be noted that the results of the questionnaire survey on the scales "Breast side effects were not evaluated" in connection with the removal of the mammary gland. Also, the results of the assessment of these profiles "Hair loss" and "Sexual satisfaction" are not presented due to the large number of interviewed patients, both in the main and in the control group, who refused to answer the questions of these scales.

Conclusions The positive dynamics in the picture of the patients' state of health and higher scores of the questionnaires in the control group were revealed. Patients in the main group noted an increase in indicators such as a deterioration in emotional status and a higher level of anxiety.

Patients with metastatic lesions of the lymph nodes on the background of breast cancer have lower self-esteem compared to the control group of patients without lymphastasis due to rejection of the body image, decreased sexual activity.

1. Trifonova NYu., Prizova NS. Statistical substantiation of the need for medical and social rehabilitation in disabled women due to malignant neoplasms of the breast. Problems of standardization in healthcare. 2012; 11-12: 46-48.

2. McCormack V, McKenzie F, Foerster M, Zietsman A Breast cancer survival and survival gap apportionment in subSaharan Africa (ABC-DO): a prospective cohort study. The Lancet Global health. 2020; 8(9): e1203-e12. http://www.ncbi.nlm.nih.gov/pubmed/32827482

3. Rositch AF, Unger-Saldana K, DeBoer RJ, Ng'ang'a A, Weiner BJ. The role of dissemination and implementation science in global breast cancer control programs: Frameworks, methods, and examples. Cancer. 2020; 126 Suppl 10: 2394 404. http://www.ncbi.nlm.nih.gov/pubmed/32348574

4. Siegel RL, Miller KD, Jemal A. Cancer statistics, 2020. CA Cancer J Clin. 2020 Jan;70(1):7-30. doi: $10.3322 /$ caac. 21590 . 